\title{
RISO e LÁGRIMAS: interioridade como controle corporal das emoções ${ }^{1}$
}

Tradução de Maria Brígida de Miranda ${ }^{3}$ e Daiane Dordete Steckert Jacobs ${ }^{4}$

Tradução do Capítulo 5 do livro Performing Emotions: Gender, bodies, spaces, in Chekhov's drama and Stanislavski's theatre, de Peta Tait. Este texto aborda questões sobre a representação das emoções e os problemas de gênero na relação criativa entre a atriz Olga Knipper e o ator e diretor Constantin

Stanislavski nas montagens do Teatro de Arte de Moscou das peças de Anton Chekhov.

Palavras-chave: Olga Knipper; gênero; emoções.

${ }^{1}$ Este texto foi publicado originalmente sob o título "Laughter and tears: interiority as bodily control over emotions". In: Tait, Peta. Performing Emotions: Gender, Bodies, Spaces in Chekhov's Drama and Stanislavski's Theatre. Aldershot: Ashgate, 2002, p. 121-144. Traduzido com a permissão da autora e da Editora Ashgate, Copyright @ 2002.

2 Professor Peta Tait é dramaturga e pesquisadora com vasta obra publicada sobre atuação e teoria teatral, traçando uma abordagem interdisciplinar através dos estudos de corpo, gênero e emoções. É professora da Faculdade de Humanidades e Ciências Sociais da La Trobe Univesity, Austrália.

3 Doctor of Philosophy pela La Trobe University, Austrália. Professora Adjunta nas áreas de Interpretação e Direção do Departamento de Artes Cênicas e do Programa de Pós-Graduação em Teatro do Centro de Artes da UDESC. Diretora teatral e pesquisadora nas áreas de treinamento de ator, teatro feminista e gênero. Autora do livro Playful Training: Towards Capoeira in the Physical Training of Actors. Saarbrücken: Lambert Academic Publishing, 2010.

${ }^{4}$ Doutoranda e Mestre em Teatro pelo Programa de Pós Graduação em Teatro da UDESC. Professora Assistente I na área de voz do Departamento de Artes Cênicas da UDESC. Atriz, diretora, dramaturga e pesquisadora das áreas de voz e performance. Autora do livro Smoked Love: estudos sobre performance e dramaturgia do ator contemporâneo. Florianópolis: Editora da UDESC, 2011. 
Olga Knipper, Stanislavski e 0 ato de interpretar naturalmente

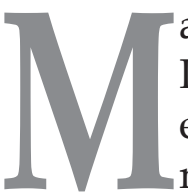

arc Slonim escreve que antes da Revolução de 1917 Olga Knipper era popular, e que "seu senso de medida, de sóbria nuance psicológica, um padrão de preparação cuidadosa do papel, fizeram dela uma incrível representante do método Stanislavski" (1963, p. 169). Esta síntese de Knipper como uma expoente do método Stanislavski ao invés de principal atriz no grupo original do Teatro de Arte de Moscou (TAM) permaneceu e é imprecisa, distorcendo a sua própria contribuição para a interpretação das personagens femininas de Chekhov. Essa afirmação ignora mudanças nas técnicas de Stanislavski e, o mais importante, as discordâncias permanentes de Knipper com a direção de Stanislavski ao longo do tempo e o descontentamento de Stanislavski com a interpretação de Knipper.

A carreira de Knipper precisa ser analisada no contexto das mulheres que trabalhavam no teatro russo no final do século XIX (Schuler, 1996, 2000), no movimento social pelos direitos das mulheres, e nas produções do TAM do drama realista europeu, incluindo as peças de Ibsen ${ }^{5}$. Embora Knipper tenha dado poucos indícios sobre sua atitude em relação aos direitos das mulheres, ela construiu uma carreira financeiramente autossustentável - uma artista independente interpretando uma ampla gama de personagens durante este período de mudança social para mulheres.

Como parte de uma geração de atrizes do final do século XIX que rejeitou a codificação gestual das emoções e tentou ofuscar a atenção do público sobre o fato de estar assistindo uma atriz em cena, a contribuição de Knipper para o teatro através de seu trabalho no TAM é formidável. Ela foi uma das principais atrizes em um teatro famoso por suas inovações em estilos de atuar na-

${ }^{5}$ Para uma lista das peças dirigidas por Stanislavski, incluindo as produções do TAM, ver Benedetti (1988, p. 332-333). turalmente ${ }^{6}$. Porém, suas conquistas profissionais são invariavelmente atribuídas a sua relação pessoal e profissional com Stanislavski e Nemirovich-Danchenko, ao TAM, e ao seu casamento com Chekhov. Além disso, a reputação profissional de Knipper como atriz foi afetada por julgamentos morais sobre seu comportamento fora dos palcos, o que joga sua vida pessoal como esposa dentro da sua persona cênica (Tait, 1997). Os comentários em língua inglesa que se referem à Knipper oferecem um fascinante estudo de caso de como palavras emotivas e a seleção de frases têm um poder persuasivo, que reflete valores de gênero específico ${ }^{7}$ e distorce os relatos sobre o trabalho de interpretação da atriz.

Nos anos de 1890 o movimento pelos direitos das mulheres estava bem estabelecido na sociedade russa, se não no teatro russo. Contudo, como nota Barbara Engel, as mulheres ainda precisavam casar ou continuar a viver com seus familiares (Engel, 1983, p. 4). A intrépida independência das mulheres russas no teatro tinha, por exemplo, Anna Brenko, uma atriz do Teatro Imperial de Mali. Ela fundou e dirigiu sua própria companhia de teatro, o Teatro Pushkin, em 1880 (Edwards, 1966, p. 2122). A companhia existiu por dois anos e envolveu um total de setenta e cinco pessoas. O mais importante: a companhia pretendia criar um grupo de atores para trabalhar em longos processos de ensaio para a produção de teatro sério, bem antes do surgimento do TAM. Brenko foi provavelmente a primeira atriz russa com formação superior, e embora ela tivesse opiniões liberais, estava motivada por seu interesse em desenvolvimentos estéticos (Schuler, 1992, 91-92).

Dado este cenário, a decisão de Knipper de buscar formação como atriz em 1895 a fim de trabalhar no teatro não é um marco em si. Desde o início ela trabalhou

\footnotetext{
6 Enquanto atores individuais talvez tenham sido elogiados por sua "naturalidade" em tempos anteriores, no final do século XIX surgiram grupos de atores que renunciaram à apresentação gestual e declamatória, em favor de estilos mais claramente discerníveis de atuar naturalmente, em correspondência ao naturalismo e a encenações baseadas na estética da quarta parede (Cima, 1993) e ao realismo no teatro.

7 o termo original é "gender-defined". [Nota das Tradutoras].
} 
duro e foi uma dedicada artista. Ronald Hingley (1989) afirma que Knipper era uma atriz extremamente versátil, capaz de interpretar uma ampla gama de papéis. Nos seus trinta e poucos anos ela interpretou os papéis de Arkadina, em A Gaivota, que tinha um filho adulto; Madame Ranevskaya em $O$ jardim das cerejeiras, com uma filha adulta; a linda Helena em Tio Vânia; e Masha em As três irmãs. Este último papel se tornou sua assinatura. Karl Kramer identifica Masha como personagem central para a estrutura de As três irmãs, do mesmo modo que Ranevskaya é a personagem chave em $O$ jardim das cerejeiras (Kramer, 1984 , p. 300). Knipper foi a primeira atriz a interpretar Ranevskaya e Masha, então ela tem sido identificada com dois dos principais papéis para atrizes no teatro do século XX. Ela interpretou Ranevskaya pela última vez em 1948, aos oitenta anos.

Harvey Pitcher, o biógrafo de língua inglesa de Knipper, defende até certo ponto sua reputação como atriz. Enquanto a descreve como parte da "inteligência liberal" e reconhecendo que ela poderia se transformar em diferentes tipos de personagens (Pitcher, 1979, p.179), ele, no entanto, reforça a opinião de V.V. Shverubovich de que "uma boa atriz" deveria trabalhar em outros teatros. Pitcher sugere que suas conquistas foram apenas por seu amor ao TAM, sua autodisciplina e sua habilidade para trabalhar em grupo. Ainda assim, estas poderiam ser qualidades admiráveis. A integridade do compromisso de Knipper com o TAM era essencial para o sucesso do teatro e sua abordagem de trabalho em grupo, que estabeleceu precedentes para novos caminhos no teatro do século XX.

Knipper ganhava um modesto salário de setenta e cinco rublos por mês para interpretar papéis principais (NemirovichDanchenko, 1968, p. 138). Em uma carta para Chekhov, Knipper explicou: "Às vezes eu odeio violentamente o teatro, outras vezes eu o amo loucamente. Ele tem me dado muita vida, muita dor, muita alegria, e ele me deu você e me transformou em uma pessoa" (Knipper apud Simmons,
1962, p. 565). O amigo de Chekhov, Maxim Gorky, descreve Knipper como inteligente e como "uma artista divina" (Gorki apud De Maed-Soep, 1987, p. 147). Ela era altamente bem respeitada por alguns dos mais importantes artistas teatrais do seu tempo, e tinha o que Elena Polyakova chama de "verve irreprimível" (Polyakova, 1982, p. 113). Nemirovich-Danchenko foi seu professor antes da formação do TAM, e descreveu Knipper como uma das estudantes mais talentosas que ele encontrou. "Adequada na aparência, uma voz boa, um tom naturalmente confiante, interpretação com refinamento e inteligência em seu todo" (Nemirovich-Danchenko apud Pitcher, 1979 , p. 20). Knipper se formou em sua turma de interpretação com a mesma nota de seu colega masculino, o aclamado Vsevolod Meyerhold.

Nemirovich-Danchenko avaliava minuciosamente a interpretação de Knipper em seus papéis. Ele descreve Knipper como tendo "charme, simplicidade e qualidades afectantes", mas ele sentiu que ela interpretou Ranevskaya com muito "drama" ao invés de "irreverência e extrema frivolidade" (Nemirovich-Danchenko apud Senelick, 1985a, p. 218). Efros, que participou das primeiras produções do TAM como crítico teatral, discordou e sentiu que a interpretação de Knipper de Ranevskaya era precisa, sem exagero, e transmitindo as qualidades superficiais e deliciosas da personagem, de forma que seus sorrisos e lágrimas aconteciam ao mesmo tempo (Chekhov apud Efros, 1974, p. 132). Para Chekhov, Knipper era uma "atriz incomum" (Pritchett, 1988, p. 179) e sua interpretação de Irina na produção do TAM de Tsar Fiodor foi "excepcionalmente boa" (Chekhov apud Magarshack, 1970, p. 324). As conquistas de Knipper merecem ser consideradas por seu próprio mérito.

A reputação de Knipper como atriz se incorporou a sua posição de amante de Chekhov, e depois de esposa, e continua sendo vista por esta perspectiva, apoiada em narrativas biográficas que retratam Chekhov como um marido relutante (Ma- 
garshack, 1970; Saunders, 1960; Simmons, 1962; Priestly, 1970; Hingley, 1989) ${ }^{8}$. Donald Rayfield (1997) sugere que sua independência e possível infidelidade fizeram Chekhov infeliz, enquanto descreve como ele abraçou um ambiente promíscuo, que rejeitava os valores burgueses. Chekhov talvez tenha apelado como marido porque ele não se propôs a cuidar de Knipper, juntamente a todas as dependências pessoais e sociais que isso poderia envolver. Sem dúvida, ele valorizava a autossuficiência de Knipper (Clyman, 1985, p. 29) e sua capacidade para ganhar o seu próprio sustento, e ele não a considerava como uma esposa dependente, embora ele talvez não a visse como uma igual ${ }^{9}$. Knipper estava dividida entre a dedicação à carreira no TAM em Moscou e sua crença de que, se ela fosse uma esposa carinhosa, ela estaria cuidando de Chekhov em Yalta, na Criméia. Knipper foi citada por J.B. Priestley, que contribuiu com certa linguagem emotiva de sua autoria, ao dizer: "'Nós estamos transformando nossa vida em uma confusão', ela gritou. 'Meu Deus, se ao menos eu soubesse que você precisava de mim, que eu poderia lhe ajudar a viver, que você se sentiria feliz se eu estivesse sempre perto de você! '" (Priestley, 1970, p. 54). Knipper manteve-se trabalhando no teatro com constante encorajamento de Chekhov.

Nos estudos sobre Chekhov, os comentários sobre Knipper são frequentemente introduzidos por uma observação aparentemente casual de que ela não era bonita. Comentários de que seus lábios eram muito finos (Pitcher, 1979, p. 54), de que ela não tinha nenhum "atributo fantástico" (Pitcher, 1979, p. 179), ou que a natureza não

\footnotetext{
${ }^{8}$ A descrição de um encontro fortuito com um homem importante é uma característica comum nas autobiografias de atrizes do século XIX (Postlewait, 1989). Existe a evidência de algumas atrizes que estavam inseguras com suas próprias identidades e que diminuíram suas próprias autoimagens em relatos pessoais (Postlewait, 1989, p. 264 (Spacks). Suas autopercepções talvez tenham refletido atitudes sociais; a identidade pessoal da atriz era geralmente submergida nas expectativas públicas dela.

${ }^{9}$ Ao que parece, Chekhov chateou Knipper porque ele não a tratou como uma parceira intelectual, e parecia evitar discussões relevantes com mulheres em suas cartas (Llewellyn Smith, 1973, p. 177-179). Magarshack observa: "Era como se, ao abrir o coração para ela, ele tivesse ao mesmo tempo fechado e trancado a porta para sua mente" (Magarshack, 1970, p. 354). Enquanto a necessidade de Knipper de ser vista como uma igual era frustrada, o suporte e encorajamento de Chekhov ao seu trabalho profissional parecia iluminado. Em defesa da relação, Laurence Senelick avalia o casamento como tendo sido um "sucesso" (Senelick, 1985b, p. 14).
}

tinha sido generosa com ela (Slonim, 1963, p. 170), indicam que Knipper é julgada por sua aparência física de acordo com o ideal masculino de beleza feminina. Knipper pode ter sido uma das mais bem sucedidas atrizes de drama sério de seu tempo, mas ela não era considerada bela. Isso parece ter influenciado as percepções sobre ela nos estudos acadêmicos das décadas seguintes, a despeito do respeito que ela ganhou de seus contemporâneos. Slonim expressa a opinião massiva que se tinha de que ela atingiu a "perfeição por meio do trabalho incessante e da preparação consciente" (Slonim, 1963, p. 170). Por outro lado, David Magarshack reconhece o "brilho" profissional de Knipper enquanto questiona seu comportamento pessoal (Magarshack, 1970, p. 362). O reconhecimento de seu trabalho é continuamente temperado por julgamentos sobre sua aparência e comportamento pessoal em seu casamento. Os mundos profissional e pessoal da atriz feminina são percebidos como intercambiáveis e passíveis de vigilância.

O mais importante é que Knipper e Stanislavski atuavam juntos nas produções do TAM. Oliver Sayler descreve que os três grandes momentos em As três irmãs eram entre Knipper e Stanislaski, como Masha e Vershinin: a entrada deles e a declaração de amor no começo do ato II; as trocas de Tra-ta-ta ${ }^{10}$ no ato III; e "a despedida mais profundamente tocante do teatro moderno" no ato IV (Sayler, 1922, p. 52). Ele atribui estas cenas ao gênio de Stanislavski (Sayler, 1922, p. 52). Mas é a combinação de Knipper como Masha e de Stanislavski como Vershinin, os amantes na primeira produção de As três irmãs, que se tornou um importante ponto de referência na história da interpretação teatral (Nordmann, 1994, p. 137). Sayler também acredita que as performances de Knipper e Stanislavski (como Gayev) em O Jardim das cerejeiras tornou-se um ponto alto no teatro moderno (Sayler, 1922, p. 23), e elogia a interpretação de Knipper, porque ela transforma-

\footnotetext{
${ }^{10}$ Brincadeira com onomatopeias criada por Chekhov no texto de As três irmãs. [Nota das Tradutoras].
} 
se de uma mulher do mundo no retrato de uma mãe carinhosa (Sayler, 1922, p. 57). A contribuição artística de Knipper é notadamente aclamada quando sua personagem apresenta um comportamento de carinhos e cuidados.

Knipper admirava a habilidade de Stanislavski de se transformar em uma personagem. Nos seus relatos do trabalho deles juntos, Knipper descreve uma dinâmica de atuação de suas personagens em relação aos olhares, às respostas emocionais e às entonações das personagens de Stanislavski, Astrov, Vershinin e Gayev (Knipper apud Stanislavski, 1963, p. 88-91). Knipper admirava Stanislavski como Vershinin e suas expressões de reações emocionais complexas. Quando Stanislavski comparava Knipper à outra atriz em 1905, Savitskaya, ele descrevia Knipper como uma "grande atriz-chave", que poderia "comandar", enquanto Savitskaya era "sempre reprimida" e incapaz de "desvelar seus sentimentos" (Stanislavski, 1966b, p. 44). Ele reconhecia os pontos fortes de Knipper, como a habilidade de segurar a atenção e de revelar emoções. Ambos expressavam admiração mútua pelo trabalho um do outro. Portanto, parece razoável questionar por que Knipper tinha dificuldades com a direção de Stanislavski desde as primeiras produções das peças de Chekhov, e especialmente desde 1909, no período em que ele começou a formalizar o seu sistema, e por que ela não se tornou um expoente deste.

Stanislavski dirigiu Knipper em um significante número de produções do TAM. Mas suas interpretações da personagem nem sempre refletiam o que ele almejava para sua atuação. É significativo que ele a retirou da personagem de Masha, em As três irmãs, mas Nemirovich-Danchenko interveio, e ela foi reestabelecida na personagem. Stanislavski também substituiu Sudbinim com os ensaios bem adiantados. Jean Benedetti relata que quando Knipper queria fazer a confissão de Masha de seu amor por Vershinin "com um tom de alta, quase desesperada emoção - uma mulher suplicante abrindo seu coração", tanto Sta- nislavski quanto Nemirovich-Danchenko rejeitaram a proposta dela e usaram um "controle físico na cena" (Benedetti, 1988, p. 107-108). Consequentemente, Chekhov concordava com Nemirovich-Danchenko sobre a explícita teatralidade de Knipper.

\section{Knipper escreve para Chekhov:}

Stanislavski diz que eu estou dramatizando muito. O papel ainda não chegou a ferver, você sabe. $\mathrm{O}$ ponto de discordância com Nemirovich é a confissão de Masha, no ato III. Eu quero fazer a confissão de Masha num estado de nervos, com oscilações, ou seja, a confissão é forte, dramática, i.e. o peso da situação supera a alegria do amor. Nemirovich-Danchenko quer essa alegria do amor, de tal forma que, a despeito de tudo, está tão cheia deste amor, e não o confessa como se fosse um crime. $\mathrm{O}$ segundo ato é cheio deste amor. Para Nemirovich o ato quatro é o clímax, para mim é o ator três. (Knipper apud Benedetti, 1996, p. 93 (15 de janeiro de 1901). ${ }^{11}$

Laurence Senelick acredita que Knipper foi precisa em relação ao seu papel, mas não à peça, e observa que a personagem desafiava valores sociais (Senelick, 1997, p. 61). O que é importante é que a explicação de Knipper para sua abordagem é específica na sua descrição de Masha cometendo um crime. Richard Stites explica que, naquela época na Rússia, o adultério com uma testemunha ocular era a única premissa para divórcio, e era um crime (Stites, 1978, p. 182). O desejo de Knipper de mostrar o nervosismo de Masha parece completamente justificável tendo em vista o risco da situação e sua perspectiva feminina da seriedade da mesma.

Deve ser observado que esta não era

\footnotetext{
11 Senelick traduz: "Eu quero fazer o ato todo nervosamente, com oscilações, o que significa que a confissão poderia ser poderosa, dramática, a escuridão das circunstâncias que a cercam ganha vantagem sobre a alegria de estar apaixonada. Nemirovich prefere esta alegria de estar apaixonada, de modo que Masha, apesar de tudo, está repleta deste amor, e faz sua confissão não como um crime. $\mathrm{O}$ ato II está cheio deste amor. Na interpretação de Nemirovich, o ato quatro é clímax, na minha é 0 ato três" (Senelick, 1997, p. 61). [Nota das tradutoras: Esta é uma tradução da mesma passagem feita por Senelick, e proposta como tradução alternativa por Peta Tait. Para comparações, veja páginas 125 e 143 da obra original].
} 
apenas uma abordagem de Knipper para a interpretação das emoções, mas uma interpretação dessa personagem em particular em um conjunto específico de circunstâncias. Antes desse papel, Knipper teve grande dificuldade para fazer a interpretação "explosiva" de Helena em Tio Vânia, imposta por Stanislavski e Nemirovich-Danchenko, querendo ao invés disso criar uma personagem mais apática e fria (Pitcher, 1979, p. 192). As interpretações de Stanislavski das reações das personagens femininas talvez tenham sido falhas. Por exemplo, com Arkadina em A Gaivota, a sua direção para Knipper caminhar com as mãos nas costas quando está nervosa, depois que Treplev pára sua peça, choca J. L. Styan como uma ação inapropriada para uma atriz acostumada a atrair atenção (Styan, 1971, p. 36n2).

Meyerhold enfatiza que a criatividade dos atores do TAM era geralmente muito mais livre nas produções de A Gaivota e Tio Vânia do que quando Stanislavski impunha o seu tom e sua abordagem de grupo em As Três Irmãs e em O Jardim das Cerejeiras (Meyerhold, 1969, p. 32-33). Nick Worral relata que Stanislavski demonstrava as personagens masculinas e femininas nos ensaios para As Três Irmãs, enquanto Nemirovich-Danchenko dava instruções verbais (WorraL, 1996, p. 135). Quando Knipper interpretou Regina em Os espectros de Ibsen, em 1905, ela teve dificuldades em manter a interpretação da personagem e em encontrar uma maneira de falar satisfatória, assim como teve uma insatisfação com sua interpretação de Masha. Stanislavski, como diretor, tentava solucionar o problema, demonstrando como uma personagem feminina deveria mover-se (Benedetti, 1988, p. 143-144). Benedetti escreve que Stanislavski via a voz vinda da manifestação física de impulsos internos (Benedetti, 1988, p. 144). Por que Knipper teve dificuldades com o estilo de direção de Stanislavski nesse caso? Pitcher afirma que Knipper não podia copiar, e tinha de encontrar o seu personagem "de dentro" (Pitcher, 1979, p. 183). Mas ela parecia sentir dificuldades em copiar a concepção de Stanislavski da expressão física do "de dentro".

Enquanto expressa gratidão e admiração por Stanislavski, Knipper diz: "Eu fui cativada por ele, eu o temia, o reverenciava, e algumas vezes, o 'odiava'". E sobre as suas exigências: "era uma tortura e uma alegria trabalhar com ele", e os ensaios eram torturantes até que ele estivesse satisfeito (Knipper apud Stanislavski, 1963, p. 83). Knipper atribui a ele motivos desinteressados e nobres em sua dedicação ao teatro.

Embora Stanislavski supostamente tenha mudado seu estilo ditatorial de direção em 1906 para o estilo pedagógico de "parteira", provocando maior entendimento através do questionamento (Jones, 1986, p. 43), ele permaneceu paternalista (Carnicke, 1984, p. 482). Em outros momentos, ele parece ter sido emocionalmente manipulador. No início do relato detalhado de Nikolai M. Gorchakov do processo de pesquisa de Stanislavski em 1924 está a descrição de uma atriz desmanchando-se em lágrimas. Interpretando a personagem de Marion em $A$ Batalha da vida, de Charles Dickens, Stepanova acha difícil chorar de pena na leitura de uma balada. Stanislavski faz a atriz chorar, falando severamente com ela. Ele diz: "Eu definitivamente sei que quando Marion lê a balada ela chora amargamente" (Gorchakov, 1973, p. 83). Ele pede então à atriz para analisar por que a personagem sente pena, e declara isso como autopiedade, explicando que ele fez a atriz chorar para experienciar a mesma emoção. Ele não tolera a sugestão de Stepanova de que a personagem tem uma capacidade para empatia ou compaixão altruísta. A resposta da atriz no ambiente social do processo de ensaio, porém, podia igualmente ser entendido como lágrimas de raiva em reação a sentimentos de impotência (Crawford et al, 1992, p. 174). Stanislavski também reduz Molchanova a lágrimas de medo quando a abandona na escuridão, supostamente colocando a atriz em uma experiência análoga à cegueira, alegando que isso a ajudará a desenvolver a atitude correta para sua personagem (Gor- 
chakov, 1973, p. 298). Dado que as mulheres podem experienciar o medo diferentemente dos homens, e que são mais vulneráveis em situações de risco que reforçam sua impotência em uma hierarquia de interações sociais de gênero (Crawford et al, 1992, p. 104), esses exemplos, de atrizes chorando em ensaios, sugerem a imposição e distorção de definições masculinas tanto para a interpretação de reações emocionais quanto para o desequilíbrio de poder. Não existe relato comparável de intérpretes masculinos chorando em traduções inglesas. Existe um relato de um ator praguejando contra si mesmo depois que Stanislavski interveio repetidamente dizendo "Eu não acredito em você", e em seguida, desafiando Stanislavski com a mesma interjeição para fazê-lo demonstrar oito vezes (Stanislavski, 1963, p. 138 e p. 140). Stanislavski admitiu surpresa, descrença, e em seguida, a aceitação de críticas a sua interpretação nos ensaios em 1913 e 1914 (Stanislavski, 1966a, p. 26).

Knipper teve que incorporar qualidades emocionais como instruído fisicamente, a fim de trabalhar de acordo com a indicação de Stanislavski e NemirovichDanchenko de controle físico sobre as cenas. Isto restringiu sua interpretação. Knipper escreve sobre Helena, de Tio Vânia:

O problema para minha mente é este: eles queriam que eu esquecesse minha própria interpretação de Helena, porque o diretor [Stanislavski] a achou entediante, mas eu não pude seguir minhas ideias até o final. Eles impuseram uma personagem diferente para mim, dizendo que era essencial para a peça. Eu segurei por muito tempo e fui contra isso até o fim. No ensaio geral, eu estava calma, e talvez por esta razão atuei com facilidade e calmamente. Na noite de estreia eu estava terrivelmente nervosa e absolutamente em pânico, algo que nunca me aconteceu antes, e então foi difícil interpretar uma personagem que me tinha sido forçada. Se eu tivesse podido interpretar a personagem como eu queria, a primeira noite provavelmente não teria me preocupado tanto. (Knipper apud Benedetti, 1996, p. 24
(27-29 de Outubro de 1899).

Somado-se a isso, Knipper talvez estivesse balizando entre a interpretação do diretor e a interpretação do dramaturgo das personagens. Por exemplo, quando Helena se despede de Astrov ela foi dirigida por Stanislavski, em uma cena de extrema paixão, enquanto era instruída por Chekhov que esta deveria ser uma partida casual, uma vez que Astrov não ligava para Helena (Styan, 1971, p. 136n1). Neste caso, a atriz estava possivelmente desafiando a autoridade do diretor sobre o significado emocional do texto teatral, em concordância com a interpretação do autor. Parece que, independentemente de sua própria abordagem, Knipper experienciou dificuldades para satisfazer as expectativas dos diretores do TAM e do dramaturgo sobre a atuação da representação das emoções.

Portanto, é discutível até que ponto Knipper podia aplicar a sua caracterização sua própria experiência e entendimento das emoções - uma premissa da abordagem de Stanislavski para a atuação após 1909. É importante ressaltar que os atores do TAM eram estimulados a minimizar seus gestos corporais, e retratar o autocontrole das emoções usando uma composição externa (Balukhaty, 1952, p. 35). Knipper dominou esta técnica. Nemirovich-Danchenko aconselhou Knipper a não usar nem mesmo movimentos expressivos de mãos (Pitcher, 1979, p. 183). Os comentários de Stanislavski indicam que ele também elogiou Knipper por seu controle corporal. No papel da Condessa de Lenier, na produção de 1927 de As Irmãs Gérard, Stanislavski confirma que Knipper estava: "Perfeitamente certa no uso da extrema economia de movimentos externos. Por isso, seu diálogo e sua ação com as palavras se tornam até mais fortes." (Stanislavski apud Gorchakov, 1973 , p. 295).

Knipper limitou os movimentos e gestos de seu corpo físico com o intuito de focar a atenção na sua expressão emocional em suas falas. As emoções são manifestadas através da voz, então a atriz produz uma imaterial, porém reconhecível, presença emocional. Knipper também foi ins- 
truída a comunicar expressões emocionais e pensamentos em silêncio para um ator. Gorchakov escreve que Knipper "olhou para seu parceiro e então olhou para o lado, com desconfiança e admiração. Nós imediatamente adivinhamos, a partir da expressão de seus olhos, a primeira fala de seu papel." (Gorchakov, 1973, p. 316).

Ela estava atuando em uma silenciosa, mas visual, linguagem das emoções. O estilo de interpretação de Knipper envolveu a restrição de seus trejeitos físicos e gestos exteriores com o objetivo de mostrar sua personagem experienciando emoções. Sem dúvida, Knipper dominou o novo estilo de interpretação associado ao realismo do TAM, com sua contenção física, sua premissa de interpretação "de ser" no palco, e seus modos sutis de entrega emocional para retratar mundos interiores.

Knipper concordou com as ideias de Stanislavski de interpretar emoções opostas. É particularmente significativo que, por exemplo, o crítico Nikolai Efros reconheceu a capacidade de Knipper de atuar com risos e lágrimas ao mesmo tempo quando ela interpretou Ranevskaya. Para dar uma impressão de luta da personagem para recuperar o controle emocional, interpretando uma combinação de emoções opostas, é necessário um considerável grau de habilidade por parte da atriz. Esta abordagem permite que uma emoção possa suplantar outra, de modo que parece ser um ato de controle sobre um impulso emocional para rir ou chorar, seguido de outro impulso emocional. Evidentemente, Knipper podia revelar estas emoções contraditórias como conflitos internos.

A ação deliberada de parar um riso com uma emoção oposta, como o choro, ou vice-versa, sem o uso de gestos, cria a impressão de que essas emoções estão em conflito dentro do corpo. No teatro, estas respostas emocionais devem ser reproduzidas através da superfície visível do corpo, e, neste exemplo do trabalho de Knipper, com movimentação física mínima. A interpretação de emoções opostas confirma que emoções singulares e reconhecíveis trans- formam-se em outras emoções. Esta manipulação deliberada de emoções requer um entendimento de como as emoções podem ser compreendidas em suas performances sociais corporificadas, a despeito de como elas são subjetivamente experienciadas pela atriz.

No entanto, Knipper não pareceu se adaptar facilmente aos experimentos em andamento de Stanislavski de técnicas de atuação, particularmente com respeito às emoções. Como o diretor de Um mês no País em 1909, Stanislavski removeu movimentos e gestos a fim de maximizar o foco nas emoções internas da personagem (Edwards, 1966, p. 90; Worral, 1996, p. 191). Ele deu instruções detalhadas de mudanças para Natalia Islaieva, interpretada por Knipper. Os ensaios não evoluíram de acordo com a expectativa de Stanislavski. Benedetti relata:

O problema principal era Knipper. Ela tinha começado bem o suficiente, mas ela foi completamente derrubada quando Stanislavski começou a aplicar seu novo método. Ele tinha estado em conflito com ela antes. Ele a tinha acusado de estar preguiçosa, de nunca estar pronta na estreia. Isto era um pouco injusto, já que ele mesmo estava longe de ser um ator de estreia... Mas a diferença entre eles era que ele tinha um método de trabalho, e ela não. Ela era uma atriz instintiva, mas seu alcance era limitado. Quando seu instinto falhava, como neste caso, ela ficava perdida, e como ela achou as novas ideias de Stanislavski muito "intelectuais", ela não estava preparada para ser ajudada. Ela estava tentando, como Stanislavski suspeitou que ela faria, abordar o papel a partir do exterior. Análises psicológicas estavam perdidas nela. (Benedetti, 1988, p. 183).

Benedetti parece sugerir que, nesta ocasião, Knipper estava fisicalizando a personagem através de uma abordagem do papel a partir do "exterior", ao invés de dentro. A peça e a interpretação de Stanislavski e Boleslavski foram consideradas 
bem sucedidas, previsivelmente Knipper pensou ter falhado. Parece haver alguma confusão se o problema percebido na interpretação de Knipper resultava de uma interpretação inaceitável da psicologia da personagem, ou se sua inabilidade de atuar de dentro resultava do regime de Stanislavski, que determinava a fisicalização externamente.

Knipper, porém, descreve seu terror e medo de que ela não entenderia as "sutilezas emocionais" exigidas dela, e descreve como ela chorava durante os ensaios e eventualmente não conseguia permancer na sala de trabalho até o fim das sessões (Stanislavski, 1963, p. 84). Isso era uma discordância sobre emoções. Na descrição de Benedetti sobre o processo de trabalho, Knipper é culpada pelos problemas, porque ela não entende o novo sistema. Não há tolerância para a possibilidade de que ela poderia ter discordado da abordagem, já que esta parecia inibir, ao invés de melhorar, seu desempenho. Nesta interpretação do que aconteceu, que também presume uma hierarquia do pensamento sobre o estado emocional, o diretor é considerado a figura detentora de todo o conhecimento, e a atriz a sem conhecimento. Em comentários sobre o conflito deles, Knipper é acusada de ter percebido "as limitações de sua abordagem intuitiva para a interpretação" (Pitcher, 1979, p. 188). Seu "fazer" intuitivo como uma intérprete é julgado inferior para o processo de análise de Stanislavski. Contudo, a correção da atuação era avaliada pelo diretor de fora. Nesta ocasião, Stanislavski é visto como tendo curado a ferida elogiando o talento e os dons de Knipper, sem fazer concessões a ela, dizendo “'Eu prometo não assustá-la com jargões técnicos' [...] Depois, ele aconselhou-a a usar sua própria personalidade, sua própria psicologia." (Benedetti, 1988, p. 183184). Worral defende Knipper quando ressalta que enquanto ela estava arrependida e culpada (Worral, 1966, p. 185), a expressão de Stanislavski era "quase mística", citando longos trechos de seus cadernos de anotação. Isto explica porque Knipper teve dificuldades de seguir a direção (Worral, 1966, p. 186-189). O mesmo fez Nemirovich-Danchenko (Worral, 1966, p. 192-193). Inegavelmente, as emoções carregadas da sala de ensaio devem ter contaminado, se não impedido, a atuação de Knipper.

Em outros momentos de sua carreira, Knipper experienciou dificuldades em manter a concentração para criar a impressão de uma personagem feminina em luta com suas emoções interiores para a satisfação de Stanislavski. As declarações de Knipper sobre como ela não tinha uma técnica específica de atuação são usadas contra ela como evidência de que sua abordagem era, por consequência, inadequada, porque não tinha uma estrutura intelectual. Essa crítica menospreza sua experiência e realizações profissionais. Pitcher faz uma citação de Knipper na qual ela diz que a experiência dos sentimentos era a parte mais preciosa do teatro para ela (Pitcher, 1979, p. 181). Ainda assim, paradoxalmente ela é descrita como alguém que valoriza a expressão concreta sobre a abstração intelectual. A deturpação das realizações de Knipper se reflete nesta rejeição de sua abordagem como necessariamente intuitiva por não ser analítica, e na tendência de medi-la a partir de um ideal que ela não alcançou e não a partir do que ela aspirava alcançar. Ao assumir que sua abordagem era intuitiva, assume-se, portanto que era instintiva, espontânea e surgindo naturalmente, considerada típica da atuação das mulheres.

A interpretação de Knipper era assim? A reputação de Knipper para o trabalho duro contradiz essa ideia de interpretação intuitiva, e suas próprias declarações confirmam que ela usava os ensaios para progressivamente desenvolver seu papel. As abordagens do início do século dezenove consideraram a sensibilidade mais nobre que a inteligência (Talma, 1958, p. 49-50). Catherine Schuler (2000) confirma que havia na Rússia uma divisão bem estabelecida entre duas técnicas de atuação: uma de espontaneidade intuitiva, e outra de abordagens sistemáticas. Contudo, ela argumenta que a primeira frequentemente 
utilizava técnicas experienciais. Isto sugere técnicas usadas na prática ao invés de explicadas com teoria. É mais provável que os ensaios tenham facilitado uma exploração corporificada de possíveis interpretações de uma personagem e emoções para Knipper.

Se Knipper respeitou a compreensão de Nemirovich-Danchenko de psicologia (Pitcher, 1979, p. 182), mas achou difícil aceitar a interpretação de Stanislavski da personagem, ela pode bem ter se confundido pela exigência de encontrar o papel a partir de dentro. Reconhecidamente, em 1909 quando Stanislavski estava se esforçando para implementar seu sistema de atuação, Knipper estava passando por um período que Pitcher descreveu como "insegurança aguda como atriz" (Pitcher, 1979, p. 184). Ela descreve o seu próprio processo interior como caótico, e fala sobre a sua ansiedade, que ela chama "ouvindo a mim mesma no palco" (Pitcher, 1979, p. 187). Isso torna a imposição da abordagem de Stanislavski mais problemática. Inquestionavelmente, Knipper aceita a ideia de que atuar deveria envolver uma expressão ampliada de emoções selecionadas, que poderiam ser executadas efetivamente com um mínimo de gestos ou movimentos externos.

Isso não é o mesmo que a atriz explorar seus sentimentos como a fonte das emoções da personagem, e nesse quadro, Knipper sentiu que falhou, porque ela representou apenas uma fração do que ela percebeu emocionalmente. Essa constatação aparentemente imobilizou suas reações nos ensaios em 1909. Suas tentativas de reproduzir suas próprias respostas a confundiram como atriz. Ou ainda, ela não sabia o que ela sentia, ou ela sabia, mas achou que era muito confuso experimentar e interpretar personagens a partir destas respostas. $\mathrm{Ou}$ talvez, sua experiência não podia ser sequencialmente disposta de acordo com ou reduzida aos - imperativos emocionais do teatro. Talvez isso tenha contradito a aplicação da estrutura de Stanislavski para explicar emoções. Independentemente da explicação, isso sugere uma discrepância entre o aparecimento de emoções internas buscadas nessa interpretação e a experiência pessoal da intérprete das emoções.

Ao que parece, Knipper achava difícil quantificar e comunicar emoções selecionadas nos ensaios para satisfazer Stanislavski. Isso é julgado como uma falha para pensar, embora seja mais provavelmente uma diferença, decorrente da confusão sobre a seleção de certas emoções e o discurso por trás delas. Parecia, no entanto, que em certa medida, essa inabilidade para utilizar um eu emocional pessoal como fonte para a interpretação das emoções de uma personagem, na verdade, surgiu da intensa autoinvestigação de Knipper: uma escuta dela mesma na qual ela não poderia extrair as respostas emocionais exigidas. Além disso, a confiança em afirmar que a fonte das emoções para a interpretação pode ser encontrada no eu interior de cada um, como emoções distintas daquelas surgidas em um contexto social, pareceria depender de se ter uma experiência clara de que existe um eu interior autônomo como fonte. Uma atriz, confrontada por atitudes sociais que continuamente confundiram sua esfera social com a pessoal, pode ter achado esta separação difícil de manter. As percepções de uma autonomia interna poderiam ser mais aceitáveis para a experiência masculina.

Knipper não foi a única atriz que teve problemas com as novas técnicas de Stanislavski. Aparentemente, a esposa de Stanislavski, Lilina, não as achou úteis para seu trabalho em O Pássaro Azul, de Maeterlinck, em 1908 (Benedetti, 1988, p. 182) e Alisa Koonen deixou o TAM durante a nova abordagem (Worral, 1996, p. 186). A implantação do sistema tornou os ensaios muito tensos e as apresentações se tornaram cansativas (Mitter, 1992, p. 14). Em retrospectiva, a resistência das atrizes e atores do TAM à adoção formal do sistema Stanislavski em 1911 é atribuída à inabilidade de Stanislavski de explicar suas ideias de forma simples (Edwards, 1966, p. 91). É provável que sua caracterização dirigida apresentasse dificuldades para as/ os intérpretes experientes do TAM, acos- 
tumados a trabalhar suas interpretações nos ensaios. Um processo antecipado de autoinvestigação talvez tenha distorcido, ao invés de iluminado, a interpretação de reações emocionais e, como indicado, Stanislavski inverteu sua abordagem em anos posteriores. Ele passou a aceitar que a preparação para a interpretação de emoções precisava ser desenvolvida através de uma corporificação, um modo experiencial de fisicalização, ao invés de constituída na separação da mente sobre o corpo.

Todavia, as dificuldades duradouras de Knipper, abrangendo as abordagens posteriores de Stanislavski, invariavelmente elevam o espectro de experiências sexualmente diferenciadas, que incidem na interpretação. Stanislavski basicamente discordou da interpretação da personagem de Knipper, e disse:

Sentimentalismo... [ela está] apenas com medo de um sentimento genuinamente saudável, retirado das entranhas da natureza, [e] prefere sentimentos menores, mas gentis [...] Knipper... acrescenta uma dose de açúcar. É por isso que [seu] riso começa com um sorriso afetado, as lágrimas se transformam em uma lamentação coquete ou raiva, capricho feminino, etc. (Stanislavski apud Senelick, 1997, p. 69-70).

Possivelmente, Knipper abordou seus papéis com uma visão de como as personagens femininas não poderiam expressar suas emoções livremente. Senelick afirma que a Ranevskaya de Knipper era irritante ao invés de indomável, e indolentemente frívola (Senelick, 1997, p. 70). Será que ela compreendeu que a juventude de Ranevskaya, o charme espontâneo, poderiam se tornar tensos, dada a sua trágica história pessoal, e suas respostas tinham que ser mascaradas? Existe a possibilidade de Knipper ter observado como um comportamento feminino e suas qualidades emocionais envolviam a interpretação de um papel social, e de ela ter atuado com esta interpretação.

O relacionamento profissional de Sta- nislavski com Knipper permaneceu sempre difícil, e ele estava para tirá-la do elenco de sua produção de Medo, de Afinogenov, em 1932, porque ela era incapaz de capturar o tom bruto e sério que ele queria (Benedeti, 1988 , p. 305). Novamente, isso parecia uma diferença de opinião sobre a interpretação emocional da personagem, embora possa ser relacionada com este período em que ele não estava mais preocupado com técnicas para analisar emoções antes de fisicalizá-las.

As instruções de Stanislavski sobre o acesso às emoções da personagem através da experiência pessoal da/o intérprete permanecem problemáticas para as atrizes. Este processo, para interpretar uma personagem feminina, pode colidir sistematicamente com a representação de um eu social. Na estrutura realista, a encenação de um eu social pode ser direta, mas as instruções para interpretar um eu interior presumem que existe uma experiência feminina de um eu autônomo interior, que pode ser separado de sua representação social.

No trabalho do TAM, os atores eram com frequência considerados melhores do que as atrizes. Sayler, ao observar o TAM em 1917, escreve que o "O Teatro de Arte é fraco, comparativamente, em relação a suas mulheres" (Sayler, 1922, p. 23). Paradoxalmente, ao mesmo tempo ele elogia o trabalho de Knipper e de outras mulheres membros da companhia. Seriam então as emoções reveladas pelas atrizes - as condições internas de seus personagens - percebidas como reflexos da experiência social ao invés de habilidade teatral? Por exemplo, Pitcher aponta semelhanças nas reações emocionais entre Knipper e Ranevskaya, a despeito da diferença clara entre Knipper - uma mulher determinada na carreira - e a personagem de $O$ jardim das cerejeiras (Pitcher, 1979, p. 197). Por inferência, Knipper pode se tornar Ranevskya porque a personagem é como ela, e não porque Knipper seria uma atriz suficientemente competente na criação de uma personagem. Assim, diferente do ator, a ação de atuar emoções quando realizada por uma atriz é menos 
valorizada, porque ela parece replicar a crença social, ou seja, a expressão feminina das emoções que afloram naturalmente.

Considerando a estreita relação de trabalho, é de se esperar que ao longo do tempo Knipper e Stanislavski não conseguiram superar suas discordâncias. Haveria alguma divergência persistente que talvez pudesse explicar isso? Knipper relembra como ela respondia emocionalmente em cena à interpretação de Stanislavski de personagens como Astrov, Vershinin, Gayev e o Conde Shabelsky da peça Ivanov (Stanislavski, 1963, p.86-92). Ela se descreve atuando em quatro de suas personagens femininas em resposta à interpretação de Stanislavski de suas quatro personagens masculinas. Como Masha, Knipper se descreve sentindo alegria ao mesmo tempo em que fica chorosa diante da resposta de Vershinin"12. "Eu, Masha, gostava de escutar a voz dele, a qual eu aprendi a amar. E ao olhar em seus olhos, vidrados em algo distante, e eu ria baixinho de alguma emoção interior enquanto ele falava" (Knipper apud Stanislavski, 1963, p. 89). Knipper nota que as reações emocionais a partir da interpretação de Stanislavski de suas personagens a estimulavam em seu próprio trabalho de atriz. Suas expressões emocionais aconteciam em resposta à atuação de outra pessoa e ela rememora essa fisicalização da emoção. É a estimulação externa, pelo olhar, que facilita o envolvimento sensorial. Como Merleau-Ponty escreve, há uma "reversibilidade do olhar" [...] "a visão vem para completar o corpo estesiológico" (1968, p. 154). Independentemente das diferentes interpretações emocionais de Knipper e de Stanislavski das personagens, Knipper teria dificuldade em seguir as direções de atuação dadas por Stanislavski, apartadas de uma experiência interativa sensorial? Seria essa maneira de interpretar parcialmente dependente de um prévio ensaio/desempenho de emoções junto a um parceiro emocional? Indubitavelmente, a capacidade de imaginar uma

12 Knipper diz "Eu não posso lembrar da cena de minha partida com este Vershinin sem lágrimas" (Knipper apud Magarshack, 1975, p. 223). interpretação de emoções é crucial, mas, nesse caso, a corporificação das respostas emocionais de outros em atuação parece ser relevante ao processo de imaginação (e então de rememoração).

Uma atriz experiente como Knipper, colega de trabalho de Stanislavski, seria capaz de desafiá-lo, assim como de desafiar a solidez de suas técnicas - que nos primeiros anos teriam sido questionáveis. Talvez, como um comentarista sugere, Stanislavski também tenha desenvolvido seus conhecimentos ao trabalhar em um grupo teatral com Kachalov e Knipper, atrizes que indubitavelmente "mostravam a ele ricas atuações em descobertas únicas" (Hobgood, 1973, p. 151). Tanto as últimas revisões de Stanislavski de suas ideias (entre 1909 e 1911) quanto seu interesse renovado na fisicalização atestam que ele tinha consciência de que sua abordagem inicial provavelmente apresentava dificuldades consideráveis para atores e atrizes. A especulação do porque Knipper continuava a enfrentar dificuldades com as abordagens sistemáticas de Stanislavski em diferentes momentos de suas carreiras centra-se na atuação das emoções. Contudo, é inquestionável a divergência entre Knipper e Stanislavski sobre a compreensão da emoção das personagens e sobre a maneira de atuar essas emoções.

\section{Maestria Teórica sobre a Interioridade}

Knipper criava os impulsos e as motivações emocionais subjacentes das personagens por meio do que Sayler observou como o seu "controle rítmico, a sua atitude, sua reticência, e também a sua maestria intelectual e emocional" (Sayler, 1922, p. 5253). A sua maestria sobre os movimentos físicos contribuíram para a impressão da maestria sobre as emoções da personagem. Nesta maneira de trabalhar, uma atriz como Knipper é considerada mais efetiva quando parece usar emoções que de outra forma poderiam provocar uma fissura no exterior socialmente apropriado da personagem. Como Stanislavski também afirma, Knipper podia desempenhar de maneira 
muito efetiva tanto a contenção física como a impressão de controle das emoções. Ela atuava o controle de forma admirável.

O paradoxo da atuação, e portanto o paradoxo do teatro, identificado por Diderot no século XVIII, é de que a forma mais efetiva de retratar as emoções, ou a sensibilidade, é aquela em que a/o intérprete exercita o autocontrole e o julgamento racional. Diderot escreve que: "a voz entrecortada [...] os membros trêmulos, os desmaios, os acessos de fúria - tudo isso é puro arremedo [...] como uma ginástica qualquer, que usa apenas a força corporal" (1957, p. 19). $\mathrm{O}$ ator ou a atriz devem se manter frios e imparciais quando comunicam a paixão. Se ele ou ela experimenta a emoção real que está sendo retratada durante a apresentação, então o ator ou a atriz seriam incapazes de continuar. Diderot conclui que um bom ator, uma boa atriz, deve fingir "alegria, tristeza, sensibilidade, admiração, ódio, doçura" (1957, p. 71). Comparativamente, o estilo de atuação associado às primeiras produções do TAM envolviam um grande refinamento das noções de controle físico e de racionalização na atuação. O que faz esta atuação diferente é que o ator/a atriz deve dar a impressão de que ele ou ela está experienciando as emoções da personagem ficcional, sugerindo assim uma batalha interna do corpo para ganhar controle, ao invés de narrativas dramáticas sobre o triunfo da razão. O estilo de atuação do TAM se apoiava em atos de autocontrole até o clímax. Ainda um ator/uma atriz deve imaginar emoções de forma que não o/a inibam, ou abafem a interpretação. Essa atuação não é apenas a fala sobre o controle das emoções e sua expressão vocal e gestos, mas também exige sua fisicalização, um fazer corporal que controla as emoções.

Uma "retórica do controle" (Lutz, 1990, p. 71 (Rosaldo) é evidente nas descrições de como as emoções eram desempenhadas no estilo de atuação verossímil desenvolvido no TAM, sob a direção de Stanislavski. Essa noção do controle em estilos realistas de interpretação confirma um sistema de valor no qual uma expressão descontrolada de emoção poderia romper a estabilidade da ordem social ou moral. Há diferenças sexuais, no âmbito social, no exercício do controle emocional. Como Lutz argumenta, enquanto homens e mulheres experienciam emoções, as mulheres as discutem e as monitoram mais, engendrando-as ${ }^{13}$. Ao assumir atos de autocontrole emocional, as mulheres evitam maiores controles coercivos externos ${ }^{14}$. Lutz explica como podemos encontrar um paralelo entre essa economia social do controle das emoções na descrição de Michel Foucault (1973) a respeito da preponderância de um modelo médico de corpo na história do discurso europeu. $\mathrm{O}$ discurso social facilita a crença de que um eu feminino deve ser especialmente vigilante em relação às emoções. Ao mesmo tempo, o eu feminino se torna prisioneiro do paradoxo de ter que demonstrar emoções para ser socialmente inteligível, e isso é o que o realismo do início do século $X X$ continuava a replicar e a modelar.

Em seu estudo sobre como atores e atrizes comunicam alegria, ódio, medo e tristeza, Harald Wallbott, mostra que as atrizes são ligeiramente mais efetivas, exceto ao comunicarem ódio (Wallbott, 1988, p.104). Ele atribui a dificuldade no reconhecimento de emoções a um cruzamento dos limites de gênero. Pode-se argumentar que não apenas as emoções são selecionadas de acordo com a identidade de gênero (Lutz, 1988, p. 73), mas também que há uma construção distinta da atuação do controle entre atores e atrizes. Por exemplo, na peça $A$ Gaivota a atriz interpretando Nina pode ter de atuar controle e restrição em seu corpo físico com o objetivo de revelar tumultuadas emoções interiores, enquanto o ator que interpreta Treplev tem a vantagem de

\footnotetext{
13 Optamos por utilizar o verbo engendrar com o significado exclusivo de atribuir o peso e significado do gênero a algo antes tratado como 'neutro'. Tait usa o termo "gendering". [Nota das Tradutoras].

14 Em seu estudo qualitativo sobre considerações da experiência emocional na América do Norte contemporânea, Lutz não identifica diferenças significativas nos relatos de experiências de emoções de homens e mulheres, mas acha que seus discursos sobre emoções são significativamente diferentes. Lutz escreve sobre as mulheres: 'elas identificaram suas próprias emoções, e a elas mesmas como indisciplinadas. E elas disciplinam ambas por meio de um discurso de controle dos sentimentos. A construção de um eu feminino que este material sugere, inclui um processo pelo qual as mulheres passaram a se autocontrolar e então evitariam a necessidade de maior controle coercivo externo'. (Lutz, 1990, p. 74).
} 
poder mostrar uma perda progressiva de controle ao atuar comportamentos com o objetivo de relevar emoções como a raiva e o desespero. $\mathrm{O}$ ator atuando emoções é mais propenso a ser reforçado pelas circunstâncias dadas da narrativa dramática. Ao atuar controle sobre, por exemplo, uma expressão de tristeza ou estresse por meio de agitações corporais, a atriz é regulada pelo que parece ser sua interioridade $(\mathrm{Bu}-$ tler, 1990, p. 134-35). Isto é frequentemente mais nebuloso nas narrativas e ações do texto e poderia exigir técnicas mais apuradas de interpretação.

Assim, a atuação de emoções cria a impressão de que a substância de um eu interior é revelada pela intérprete. Esta expressão emocional encena a interioridade na atuação realista. As emoções atuadas são a expressão da intérprete, mas estas estão enquadradas dentro das ficções textuais da personagem e da narrativa dramática. A interioridade no palco realista se torna um desempenho de contenção de emoções ficcionais.

Isto implica em um domínio daquelas emoções que são tidas como ocorrências naturais. É importante notar que especialmente a atriz encena um disciplinar físico das emoções que, por sua vez, devem parecer brotar espontaneamente e inesperadamente de dentro do corpo feminino. Tal teatro oferece uma arena social na qual o autocontrole corporal é legitimado. Somase a isso que uma atriz que é alvo de vigilância nas tensões sobre o controlar e o revelar no teatro também lida com a confluência de seu eu pessoal e profissional, assim como do eu da personagem ficcional e sua interioridade corporal, em torno de experiências de controle emocional.

Em encenações naturalistas, um imperativo para atuar com verossimilhança de fato reduziu a apreciação das técnicas de interpretação da atriz, principalmente porque ela não se comunicava diretamente com a plateia. Além disso, há uma crença culturalmente estabelecida de que a atriz manifestaria o como um eu interior exige restrição. Isto geraria então um argumento circular, apoiado na suposição de que o eu feminino é tumultuado, e potencialmente incontrolável. Lutz escreve que: "As mulheres, assim como suas emotividades, são vistas ora como puras, ora como desprovidas de virtude em sua natureza" (Lutz, 1988, p.75). É certo que, se no século XIX houvesse de alguma maneira uma menor separação entre o emocional do ator e da atriz, essa separação consequentemente diminuiria na interpretação ao longo do século XX. Se a encenação de emoções pela atriz confirma a Mulher como um ser emocional, comparativamente o ator contradiz o paradigma social de masculinidade, como sendo menos emocional ao revelar as emoções internas da personagem. A exibição do que era percebido como forte emoção ressalta noções de uma boa atuação dos atores. Em contrapartida, uma boa atuação feita por atrizes é a expressão de emoções que são indicativas de uma corporificação de um eu interior, e não a exibição social de emoções. Mesmo assim, onde as atrizes interpretam papéis dramáticos - como aqueles das peças de Chekhov, as quais também mostram suas personagens como mais emocionais e/ou mais conscientes da experiência emocional interna do que as personagens masculinas - estas separações de gênero permanecem. Por implicação, a atuação realista de interioridade é engendrada, e isso era parte das inovações estilísticas do realismo do início do século XX.

A discordância entre Knipper e Stanislavski poderia ser um pano de fundo das práticas discursivas em teatro, práticas que disciplinam corpos para encenar emoções engendradas como se fossem naturais. A insatisfação do diretor com a atriz coloca em questão uma doutrina fundamental da diferença entre a experiência feminina de um eu feminino como construção social e as percepções externas da feminilidade e do corpo. Além disso, se Knipper estivesse avaliando e interpretando as respostas emocionais de suas personagens - ao invés de simplesmente imitar aquelas que eram esperadas dela - poderia surgir uma disparidade entre as emoções que eram ence- 
nadas, especialmente quando um estilo de atuação restritiva torna mais difícil precisar qual emoção está sendo encenada.

As atrizes que trabalharam em estilos inovadores de atuação no início do século XX tentaram mascarar suas atuações por trás da presença de uma personagem crível. O estilo de interpretação de Knipper pode ser visto como parte da recodificação da identidade feminina no início do teatro moderno, o qual mudou de uma demonstração clara de emoções específicas - ou seja, a demonstração de feminilidade - para a corporificação de conflitos internos e emoções e humores contraditórios. Emoções selecionadas, indicativas da interioridade feminina, deveriam ser vistas acontecendo dentro do corpo feminino.

Quanto mais uma atriz chegasse a expressar a identidade social, menos ela seria percebida em estado de atuação, enquanto que, ironicamente, os estilos realistas de atuação se apoiavam no etos mutante de que a atuação de uma experiência social de controle emocional pode criar efeito no teatro. Contrário a muitas visões nessa área de estudo, a representação de emoções desenvolvida nas primeiras produções do TAM das peças de Chekhov serve a um texto de teatro, que é culturalmente e historicamente adequado aquele momento, e não a uma verdade universal.

\section{Um Teatro Moderno de Amores Privados}

Por serem as quatro principais peças de Chekhov centradas no seio da vida familiar e em espaços socialmente considerados privados, a expressão das personagens é tida como uma revelação de foro íntimo. Há uma tensão no drama de Chekhov, onde as emoções de suas personagens femininas tanto delineiam quanto dominam o espaço privado - mundos domésticos em demonstrações de autocontrole. Ao mesmo tempo, outros buscam o amor para serem liberados das armadilhas nesses mundos. Contextualizar as emoções chekhovianas desta forma foca a extensão na qual a concepção cultural de espaços públicos e privados é dependente de uma melhor demarcação, que distinga um eu interior de um eu social por níveis de expressão de emoção (Lutz, 1988). O drama chekhoviano estabelece espaços culturais, nos quais a confissão da carência amorosa de uma personagem surge para representar a substância de seu eu interior. Traduzido para o espaço público do teatro, a expressão emocional se coloca para a experiência privada e para o eu interior - a atriz corporifica publicamente tais paradoxos emocionais sobre o amor e a emoção.

Em suas interpretações das personagens de Chekhov, Knipper preferia amálas que criticá-las. De fato, ela era crítica das interpretações que não conseguiam realçar amor e carinho (Benedetti, 1996, p. 23 (Livro de memórias). Assim, Knipper diz que recebeu ajuda para interpretar Helen e Masha, porque essas personagens estavam apaixonadas respectivamente por Astrov e Vershinin (Stanislavsky, 1963, p.86). Knipper achava mais fácil interpretar estas personagens quando havia um foco justificável para o seu amor a partir das circunstâncias dadas pela peça. Ela confirma o amor fraternal de Ranevskaya por Gayev. Por dedução, é difícil atuar amor e outras emoções como abstrações, sem a presença corporificada. Esta abordagem do ato de interpretar amor coloca em destaque a metanarrativa teatral como uma estória de amor.

As primeiras atuações realistas disfarçavam a natureza social da experiência teatral. William B. Worthen argumenta que a encenação faz do espectador cúmplice dessa "visão privada" (Worthen, 1992, p. 17). Os primeiros teatros realistas produziam a crença de que estariam encenando a emoção interior ou privada de suas personagens, mas a encenação teatral do que é socialmente designado como do interior do corpo é associada às separações de gênero. Invertendo a visão convencional, poderia ser questionado se dramaturgias como as de Chekhov inculcam noções selecionadas do que constitui a substância de emoções privadas, e alimentam a crença social nessas verdades. Um questionamento de como 
as categorias sociais de emoções e amor são construídos como verdades interiores também desafia os preceitos das epistemologias de Teatro Ocidental.

Como Gay Gibson Cima aponta, ao passo que um estilo específico de atuação foi anteriormente associado à/ao intérprete na virada do século XX, quando personagens de mulheres fortes e independentes surgiram no palco, as atrizes tornaram-se menos identificadas com os estilos de atuação, e isto foi visto como originário nos objetivos dos dramaturgos masculinos (Cima, 1993, p.5). O naturalismo no teatro se tornou sinônimo das primeiras produções de Stanislavski no TAM, e significativamente de seu trabalho nas peças de Chekhov, e foi apenas indiretamente reconhecido por meio da contribuição dos atores e atrizes. Isto significa que a encenação de emoções interiores se associou à forma dramática. Quanto mais as atrizes conseguiam fisicalizar os mundos interiores, tanto menos elas eram vistas como teatralmente inovadoras.

Cima sugere que a transição do melodrama do século XIX para os teatros naturalista e realista deve ter inicialmente parecido algo incomum para a plateia (Cima, 1993, p. 13). A plateia, acostumada a gestos codificados e ao emocionalismo exagerado, pode ter ficando incerta sobre os sentidos menos específicos que emergiam de movimentos mínimos. Teriam estas mudanças nas representações culturais da emoção um impacto recíproco na plateia, de tal intensidade que novas formas de atuação precipitaram mudanças nas percepções das convenções sociais? Para ilustrar essa possibilidade, Elin Diamond (1992), em suas ideias sobre fenomenologia da recepção, aponta o impacto transformador do teatro de Ibsen sobre as mulheres que frequentavam as matinês no século XIX. Ela explica que, "sujeitos culturais, ao adentrarem e habitarem papéis poderosos, são concebíveis capazes de transformação [...] o que coloca a identidade em uma relação instável e contingente à identificação" (Diamond, 1992, p.397). Este tipo de intercâmbio sugere que uma espectadora ou um espectador pode ativamente imaginar o palco em uma relação mimética com o/a intérprete. Ao interpretar a personagem mulher, a atriz contribui para que a espectadora ou o espectador tenha um entendimento corporificado da identidade feminina. Logicamente, poderíamos argumentar que os estilos realistas de atuação em espaços públicos implicaram em uma redefinição social de corpos femininos e de sua interioridade.

Deve-se notar que quando as/os intérpretes são visíveis na periferia do espaço teatral em momentos significantes de suas falas, enfraquecem a centralidade simbólica destas dentro do significado emocional do texto. A mise-en-scène do diretor pode manipular os significados emocionais dos textos teatrais. A despeito destes efeitos na produção, se a atriz for colocada no centro da linguagem teatral da emoção, a qual é condenada a ser culturalmente subserviente às ideias e ao pensamento intelectual - a expressão inibidora dos discursos masculinos em espaços públicos - então as implicações de atuar emoções como uma oposição resistente à ordem social são mascaradas.

O "teatro moderno de amor privado" de Chekhov perpetua, por meio das linguagens do amor, a noção de um eu interior como algo emocional. Julia Kristeva argumenta que o amor é inseparável da sua expressão através da linguagem. No argumento de Kristeva, a metáfora permite a "transferência de sentido" ${ }^{15}$ em uma "economia" quando o sujeito e o objeto não estão mais claramente separados, mas podem apenas expressar sua unificada presença pela linguagem (Kristeva, 1987a, p. 268). O amante transfere a condição de amor para outra forma, ou seja, para a linguagem. Ao mesmo tempo, esta comunicação gera a representação de atos metafóricos de amor. Portanto, é na manifestação de uma metáfora de amor que o sujeito expressa amor (emoção) e projeta aspectos de um eu interior. As linguagens do drama chekhoviano encenam uma condição gene-

\footnotetext{
15 O termo de Julia Kristeva como citado em inglês é "conveyance of meaning". [Nota das Tradutoras].
} 
ralizada de amar, que se ora se presentifica ora se ausenta de momentos específicos entre amantes na narrativa, enquanto estabelece o amor feminino como metafórico do amar. No drama, a existência de um estado subjetivo do amor da personagem é revelado por um ato da fala, que requer uma resposta de outra personagem, e/ou descrições de uma saudade de amor.

A atriz no "teatro moderno de amor privado" de Chekhov deve encenar o amor da personagem, e em alguns momentos o ser amada, na narrativa do texto dramático, assim como, por meio de sua corporificada presença no teatro. As narrativas de interpretação do amor reverberam como condições internas às linguagens do teatro. Assim, o amor de um espectador ou de uma espectadora pela/o intérprete se conecta com a encenação da narrativa dramática da/o amante/personagem, desejosa/o da união com a personagem amada, e o eu sujeito, aspirando à união com o Outro indomável e fantasioso - a/o intérprete com a personagem. A identidade feminina nas primeiras montagens realistas do drama chekhoviano sugere um eu desejoso de amor, transmitido pelo corpo da atriz como um objeto metafórico de interioridade e de emotividade: nas linguagens do teatro, uma corporificação do amor (emoção).

\section{Encenando o Natural e o Profundo}

Não era aceitável, no teatro do século XIX, que um homem exibisse o mesmo comportamento emocional extremo de uma mulher (Wilson, 1966, p. 110). As atrizes expressavam um alto grau de "sentimentalismo histriônico" (Wilson, 1966, p. 121), "quasi-histeria" (Wilson, 1966, p. 138) e "pirotecnia emocional" (Wilson, 1966, p. 129). Essas emoções eram sinalizadas externamente. Garff Wilson identifica uma relação direta entre um ideal feminino de beleza física e as representações de extremo emocionalismo no teatro. Portanto, o que significa para uma atriz, trabalhando num estilo realista no teatro de século XX, fisicalizar uma personagem comprometida a submeter suas emoções de acordo com explicações da narrativa dramática, ou seja, implementar um regime racional e lógico? Ela interpreta a submissão das emoções, que são consideradas surgidas do interior do corpo, apenas para serem novamente escondidas. Nesta crença circular, essa percepção de um interior do corpo, de uma profundidade corpórea em cena, torna-se crucial para a representação das emoções como algo que emerge naturalmente.

Lesley Ferris explica como o "natural" vem a significar qualidades específicas, tais como "energética, animada [...] vivaz" em representações de personagens femininas no teatro (Ferris, 1990, p. 136). Uma crença na naturalidade das emoções permeia o teatro do século XX, em um cruzamento com corpos engendrados. Mesmo sem ter certeza sobre até que ponto os significados da emoção seriam ou não socialmente construídos, eles são, certamente, construídos teatralmente. Lutz escreve sobre como "a natureza da emoção culturalmente construída" dos Euroamericanos permitiu que se aceitasse uma universalidade das emoções, enquanto outros campos de saber eram tratados com grande discriminação (Lutz, 1986a, p. 297).

Caroline J. Dodge Latta escreve que as atrizes devem "profissionalizar o emocionalismo geralmente identificado como de mulheres" (Latta, 1981, p. 231). Arlie Hochschild explica que: "Gerenciar amores e ódios privados é participar de um intricando sistema emocional privado" (Hochschild, 1983, p. 13). Em uma "transmutação" disso para a esfera pública, o trabalho emocional é atingido pelo "exercício emocional, por sentir as regras, e pela troca social" (Hochschild, 1983, p. 118). ${ }^{16}$ Desde que a comercialização da expressão emocional se tornou um tipo de serviço, as interpretações de atores e atrizes de narrativas de emoções privadas no palco podem ser vistas como uma forma do que Hochschild

\footnotetext{
${ }^{16}$ Como Jean Duncombe e Dennis Marsden destacam sobre a emoção, a identidade de gênero e o trabalho: "O poder e o gênero precisam ser vistos não como atributos fixos ou papéis, mas como qualidades que são constantemente reencenadas e sustentadas nos e ao longo dos relacionamentos diários (Berk, 1985; Eichler, 1981; Komarovsk, 1988, Thompson e Walter, 1989)" (Duncombe; Marsden, 1995, p. 151). Eles explicam que: "as mulheres exercitam uma grande habilidade emocional ao reconhecer, antecipar, e enfatizar junto aos humores dos outros" (Duncombe e Marsden, 1995, p. 157).
} 
nomeia "profissão emoção". Todavia, a expressão da emoção engendrou demarcações no espaço de trabalho. É significativo que Hochschild (1983) adapte as ideias de Stanislavski para fazer uma distinção do comportamento social entre a atuação superficial e profunda, onde os sentimentos emocionais se tornam objetos em uma situação de trabalho de "se mágico". Poderia parecer que as ideias de atuação de Stanislavski influenciaram percepções culturais de emoções profundamente sentidas, tais quais aquelas apresentadas por Hochschild.

Stanislavski nem provou nem contestou que sentimentos são profundos (no corpo), ao reconhecer que sentimentos eram inseguros para os/as intérpretes. Ele descobriu que emoções atuadas podem ser ativadas pela ação e pelos músculos do corpo (Stanislavski, 1961, p. 221). Elas podem ser produzidas a partir da ação muscular, como se o corpo inteiro armazenasse respostas de memórias de emoções a serem ativadas por movimentação corporal. Sendo assim, teriam as memórias musculares de corpos femininos e masculinos processos diferenciados de lembranças? Eu poderia afirmar que os limites entre os espaços interiores e o exterior dos corpos no teatro são produzidos na interpretação das emoções, envolvendo inclusive a materialidade muscular. Como indicado, uma ideia central nos estilos de atuação derivados de Stanislavski é que emoções são desempenhadas como um exercício de controle dos mínimos movimentos físicos. A atuação de naturalidade comunica profundidade, ao paradoxalmente revelar os espaços de interioridade nas superfícies dos corpos em cena. Contudo, a expectativa de uma exibição de profundidade de um corpo atuando não é a mesma entre corpos femininos e masculinos.

As mulheres em sociedades dominadas por homens refletem o que Lutz, em sua adaptação do "espelho colonial" de Michael Taussing, nomeia como um "espelho patriarcal", que é tanto perigoso quanto fraco: elas são temidas quando liberam suas emoções e desprezadas por sua fraqueza (Lutz, 1990, p. 77-8). A identidade feminina está presa em um imperativo social que designa a exibição da corporificação emocional como passiva, definindo a sua existência e confirmando a sua censura. Assim, uma perda de controle emocional desestabiliza o limiar entre um corpo interno e externo, enquanto atos de controle o reestabelece. Uma estética teatral nestes moldes de controle do emocionalismo reforça crenças sociais sobre a instabilidade do corpo feminino ao controlar suas emoções naturais, a debilidade dos limites que separam estes espaços internos e externos, e a necessidade de vigilância continua.

Uma atriz no contexto de Knipper é considerada mais efetiva quando mostra o exercício do controle corporal sobre as emoções, que representam profundidade interior. A ideia de representar emoções reais ou verdadeiras, que domina a atuação derivada de Stanislavski, mantém a noção de "profundidade", relacionando-a com uma revelação insondável do interior privado de um corpo em atuação, e a noção de "raso" como sendo social e superficial (Vineberg, 1991). A prática de mascarar emoções com outras emoções nos estilos de atuação derivados de Stanislavski, contudo, sugere que a emocionalidade existe em uma circularidade fluída, vacilante e escorregadia, pertencente a um eu social e seus espaços, ao invés de emergir das profundezas de um eu-corpo natural. Assim como se pode conceber como emoções podem ser especificadas, dissecadas e arranjadas em uma sequência lógica e inteligível de atuação, as emoções atuadas podem ser vistas como transitórias e flutuantes, e como repetições circulares e imaginadas. A expressão das emoções pelo corpo da/o intérprete pode ser vista de maneira que a fisiologia da sua superfície estaria implicada na reprodução da profundidade.

Isto levantaria uma série de questões sociais, que não poderiam ser respondidas aqui, mas que se relacionam ao grande apelo da atuação para as mulheres. Existiria uma diferença entre como as emoções 
femininas são culturalmente representadas na atuação e como estas são socialmente experienciadas? As atrizes aprenderiam a duplicar um código social de autocontrole das emoções que imitaria como o eu feminino mascara padrões contraditórios da experiência pessoal surgidos da diferença sexual? Ou, a encenação de emoções em espaços sociais, como o teatro, na verdade produziria a identidade de gênero, que é inscrita junto às tensões envolvendo o controle emocional? Assim, o atuar emoções no teatro encoraja outras performances sociais. Além disso, como os estilos posteriores de teatro se relacionam ou mesmo produzem a expressão emocional e o comportamento na sociedade? Certamente, a expressão emocional na sociedade é dinâmica, e muda de acordo com as circunstâncias históricas e culturais. O teatro é um espaço social onde é possível tanto transgredir as normas da expressão emocional como reiterá-las.

Em seu trabalho nas principais peças de Chekhov, Knipper se posicionou entre a concepção do escritor sobre as falas e as respostas emocionais da personagem, suas próprias interpretações, e as especificações do diretor das emoções que ela deveria atuar para a interioridade de sua personagem. Como uma intermediária entre estas abordagens, era exigida da intérprete feminina a interpretação e corporificação externa das camadas imaginadas pelo diretor e pelo autor sobre as emoções do corpo feminino. Talvez, essa posição entre as múltiplas possibilidades de textos teatrais de emoções e as instruções específicas dadas a Knipper para a fisicalização das emoções em cena seja metonímica da identidade feminina na sociedade. 


\section{REFERÊNCIAS}

BALUKHATY, S. D. The Seagull Produced by Stanislavsky. Trad. David Magarshack. London: Dennis Dobson Ltd, 1952.

BENEDETTI, J. Stanislavski. London: Routledge, 1988.

BUTLER, J. Gender Trouble. N.Y.: Routledge, 1990.

CARNICKE, S. An actor prepares/Rabota aktera nad Soboi, Chast' I: A comparison of the English with the Russian Stanislavski in Theatre Journal, 1984, vol. 36, n. 04, p. 481-494.

CIMA, G. G. Acting through the barricades: a search for Prototypes of feminist theatre in Turn-of-the-Century Women, 1986, vol. III, n. 02, p. 42-45.

CIMA, G. G. Performing Women. Ithaca and London: Cornell U.P., 1993.

CLYMAN, T. (Org). A Chekhov Companion. Westport: Greenwood Press, 1985.

CRAWFORD, J., KIPPAX, S., ONYX, J. et al. Emotion and Gender. London: Sage Publications, 1992.

DE MAEGD-SOEP, C. Chekhov and Women: Women in the Life and Work of Chekhov. Ohio: Slavica Publishers, 1987.

DIAMOND, E. The violence of "We": Politicizing identification in REINELT, Janelle; ROACH, Joseph (Org). Critical Theory and Performance. Ann Arbor: The University of Michigan Press, 1992, p. 390-398.

DIDEROT, D. The Paradox of Acting. New York: Hill and Wang, 1957, p. 11-71.

DUNCOMBE, J., MARSDEN, D. "Workaholics" and "whingeing women": Theorizing intimacy and emotion work - the last frontier of gender inequality? in The Sociological Review, 1995, vol. 43, p. 150-169.

EDWARDS, C. The Stanislavsky Heritage. London: Peter Owen, 1966.

EFROS, N. Tchekhov and The Moscow Art Theatre in Anton Tchekhov: Literary and Theatrical Reminiscences. Koteliansky, S.S (Org). New York: Hakell House Publishers Ltd., 1974, p. 105-135.

ENGEL, B. A. Mothers and Daughters: Women of the Intelligensia in Nineteenth Century Russia. Cambridge U.P., 1983.

FERRIS, L. Acting Women. Houndmills: Macmillan, 1990.

FOUCAULT, M. The Birth of the Clinic. Trad. Alan .Sheridan. London: Tavistock Publications, 1973.

GORCHAKOV, N. M. Stanislavsky Directs. Translation Miriam Goldina. Westport, Connecticut: Greenwood Press, 1973. 
HINGLEY, R. A Life of Chekhov. Oxford: Oxford U.P., 1989.

HOCHSCHILD, A. R. The Managed Heart. Berkeley: University of California Press, 1983.

HOBGOOD, B. M. Central conceptions in Stanislavski's System in Educational Theatre Journal, 1973, v. 25, n.02, p. 147-159.

JONES, D.. Great Directors at Work. Berkeley: University of California Press, 1986.

KRAMER, K. Love and Comic Instability in The Cherry Orchard in Russian Literature and American Critics. Brostrom, Kenneth N. (Org). Ann Arbor: University of Michigan, 1984, p. 295-307.

KRISTEVA, J. Tales of Love. Trad. Leon Roudiez. New York: Columbia U.P., 1987a.

KRISTEVA, J. In the Begining Was Love. New York: Columbia U.P., 1987b.

Llewellyn Smith, V. Anton Chekhov and the Lady with the Dog. London: Oxford U.P., 1973.

LUTZ, C. Unnatural Emotions. Chicago: University of Chicago Press, 1988.

LUTZ, C. Engendered emotion: Gender, power and the rethoric of emotional control in American discourse in Lutz, Catherine; Abu-Lughod, Lila (Org). Language and the Politcs of Emotions. Cambridge: Cambridge U.P., 1990, p. 69-91.

Magarshack, D. Chekhov, a Life. Westport, Connecticut: Greenwood Press, 1970.

MAGARSHACK, D. Stanislavsky. Westport, Conn: Greenwood Press, 1975.

MERLEAU-PONTY, M. The Visible and the Invisible. Trad. Alphonso Lingis. Evanston: Northwestern U.P., 1968.

MEYERHOLD, V. Meyerhold on Theatre. Trad. e org. Edward Braun. London: Eyre Methuen, 1969.

MITTER, S. Systems of Rehearsal. London: Routledge, 1992.

NEMIROVICH-DANCHENKO. V. My Life in Russian Theatre. Trad. John Cournos. London: Goffrey Bles, 1968.

NORDMANN, A. The actors brief: Experiences with Chekhov in Theatre Research International, 1994, vol. 19, n. 02, p. 134-142.

PITCHER, H. Chekhov's Leading Lady: A Portrait of the Actress Olga Knipper. London: John Murray, 1979.

POLYAKOVA, E. Stanislavsky. Moscow: Progress Publishers, 1982.

Priestly, j.b. Anton Chekhov. London: International Profiles, 1970.

Pritchett, V. S. Chekhov, a Spirit Set Free. New York: Random House, 1988. 
RAYFIELD, D. Anton Chekhov: a Life. New York: Henry Holt and Co., 1997.

SAUNDERS, B. Tchekhov The Man. London: Centaur Press, 1960.

SAYLER, O. The Russian Theatre. New York: Brentano's Publishers, 1922.

SCHULER, C. Anna Brenko and the Pushkin Theatre: Moscow's first Art Theatre? In Theatre Survey, 1992, vol. 33, n. 01, p. 85-105.

SCHULER, C. Women in Russian Theatre: the actress in the silver age. London: Routledge, 1996.

SCHULER, C. Materialism, Methaphysics and Theatrical Truth: Glikeriia Fedotova and Polina Strepetova in Theatre Journal, 2000, vol. 52, n. 04, p. 497-518.

SENELICK, L. Chekhov on Stage in CLYMAN, Toby (org). A Chekhov Companion. Connecticut: Greenwood Press, 1985a, p. 209-232.

SENELICK, L. Anton Chekhov. Houndsmills, Basingstoke: MacMillian Publishers, 1985b.

SENELICK, L. The Chekhov Theatre. Cambridge: Cambridge U.P., 1997.

SIMMONS, E. J. Chekhov: A Biography. Boston: An Atlantic Monthly Press Book, 1962.

SLONIM, M. Russian Theatre: From the Empire to the Soviets. London: Methuen \& Co. Ltd., 1963.

STANISLAVSKI, C. On The Art of The Stage. Trad. David Magarshack. London: Faber and Faber, 1961.

STANISLAVSKI, C. K. Stanislavsky 1863-1963. Man and Actor, Stanislavsky and the World of Theatre, Stanislavsky's Letters. Trad. Vic Schneierson. Moscow: Progress Publishers, 1963.

STANISLAVSKI, C. Director's Diary, 1905 in MUNK, Erika (org). Stanislavski and America. New York: Hill and Wang, 1966b, p. 30-45.

STYAN, J. L. Chekhov in Performance. Cambride: Cambridge U.P., 1971.

TAIT, P. The proposal reconsidered: A biography of love in CLAYTON, Douglas (org). Chekhov Then and Now. New York: Peter Lang, 1997, p. 301-311.

TALMA. Reflections on acting in MATHEWS, Brander (org). Papers on Acting. New York: Hill and Wang, 1958, p. 41-58.

VINEBERG, S. Method Actors. New York: Shirmer Books, Maxwell Macmillan, 1991.

WORTHEN, W. B. Modern Drama and the Rhetoric of Theater. Berkeley: University of California Press, 1992.

WILSON, G. B. A History of American Acting. Bloomington: Indiana U.P., 1966.

WORRAL, N. The Moscow Art Theatre. London: Routledge, 1996. 